\title{
指宿知林ヶ島陸繫砂州の断面形状特性 に関する研究 \\ STUDY ON PROFILE CHANGE CHARACTERISTIC OF TOMBOLO TOPOGRAPHY AT CHIRINGA-SHIMA ISLAND
}

\author{
長山昭夫 1 ・浅野敏之 ${ }^{2}$ \\ Akio NAGAYAMA and Toshiyuki ASANO \\ 1正会員＼cjkstart博(工） 鹿児島工業高等専門学校＼cjkstart技術室（广899-5193 鹿児島県霧島市隼人町真孝1460-1） \\ 2正会員 工博 鹿児島大学大学院教授 海洋土木工学専攻（广890-0065 鹿児島市郡元1-21-40）
}

\begin{abstract}
This study investigates topographic changes of Chiringa-shima Island tombolo by means of field survey using DGPS and point camera observation. The tombolo exhibits appearing/disappearing processes from the sea level by daily basis and altering its position by seasonally basis. The present study has revealed, unique properties as follows: The sediment forming the tombolo moves only in a narrow area between Chiringa-shima Island and Ibusuki mainland where depth is shallower than $2 \mathrm{~m}$. The forming location of the tombolo move northward during the forming period; March-June, and southward during October-December. The location change is accord with the change of the periodic wind direction. The transverse profile change of the tombolo is governed by the periodically changing wind fields.
\end{abstract}

Key Words : Tombolo profile change, Field survey by DGPS, Numerical simulation, Image data, Daily and seasonally changes

\section{1. はじめに}

鹿児島県指宿海岸とその沖合にある知林ヶ島の間 に形成される陸繋砂州(以下砂州と称寸)は日変動と 季節変動を有する特異な砂州(図-1)である。この砂 州は, 3〜10月の大潮干潮時に連結し数時間のみ出 現する特徵を有しており, 環境省選定かおり風景 100選『指宿知林ヶ島の潮風』として登録されてお り全国的に注目を浴びている。通常，砂州は1度出 現し連結されると台風等による高波浪が作用しない 限り砂州は消失寸ることはない。しかし本研究で対 象とした砂州は潮位変動と連動し出現・連結・消滅 の日変動を有することがわかっている．またこの砂 州の周辺海岸は通常の砂州の形成されや寸い海岸環 境と異なることもわかっており, 詳細な砂州の形成 過程についての解明が急がれる。これまでに著者ら は現地観測や定点カメラ観測において砂州の季節変 動・日変動特性について検討してきた。本論文はこ の砂州の断面形状特性についてアメダス気象デー タ・DGPS観測・定点カメラ観測・数值モデルによ り検討したものでる.

\section{2.アメダス気象データによる風場の検討}

これまでの研究1), 2)において砂州の出現について, 消滅期(12月-1月中旬), 遷移期(1月中旬-3月中旬),

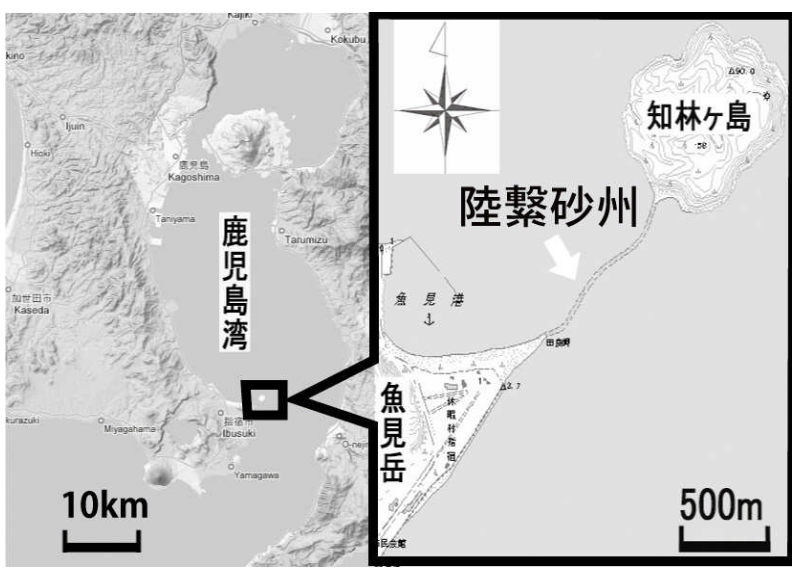

図-1 知林ヶ島陸繋砂州の全体地図 (YAHOO! 地図を加筆)

安定期(3月中旬-12月)を定義した。その定義に沿っ てアメダス気象データの検討を行い砂州周辺の風場 を考察した。外力となる風のデータは, 砂州形成位 置から約 $2 \mathrm{~km}$ 離れた指宿観測所のものを使用した。 前報 ${ }^{2}$ により指宿観測所のアメダス気象データと本 土側砂州の根元付近に設置した風向風速計のデータ を比較検討し，アメダス気象データによって現地の 風場を検討可能であることがわかっている．2008年 10月から2009年9月の風向データを, 全データ, 1012月，12-3月，3-5月，5-6月，6-9月の期間に分割し てその特性を検討した。その結果を図-2に示す。こ 
の図は各方位の頻度[\%]を示す。この図より, 対象 期間の全データのグラフ(図左上)より, 砂州周辺に おいては年間を通じて北風の頻度が最も高く, 次い で南西からの頻度が高いことがわかった．3-5月の データ(図右上)と5-6月のデータ(図右中央)より, 砂 州の安定期初期から中期にかけては, 年間を通じて 頻度の高い北風の頻度が非常に小さく, 代わりに南 風の頻度が大きくなることがわかる，6-9月のデー 夕(図右下)と10-12月のデータ (図左中央) と12-3月の データの(図左下)により, 砂州の安定期後半と消滅 期にかけて，再び北風の頻度が高くなることがわか る. 以上を総合すると, 砂州周辺においては年間を 通じて北風の頻度が最も高く, 砂州形成が行われる 安定期初期から中期にかけて, 北風の頻度が低く南 風の頻度が高くなる傾向にあり, 砂州の安定期後半 から消滅期にかけては再び北風の頻度が高くなるこ とがわかった。

次にアメダス気象データを利用し波浪推算を行っ た。波浪推算にはSMB法を使用した。波高は0.1〜 $0.2 \mathrm{~m}$ となり, 周期に関しては最大で $4 \mathrm{~s}$ 程度の結果と なった。静穏な波浪が推算されるのは，砂州が鹿児 島湾口より少し内側に位置することに起因すると考 えられる。

\section{3. 砂州を構成する底質特性}

小型GPSを用いて砂州上の底質サンプリングを 2009年9月14日と10月14日に行った。図-3にサンプ リング位置を示す，底質サンプリングは，砂州の形 成方向に沿って17地点とり, 各点の直交方向に3点 でサンプリングを行った。 その後, 採取した底質の 振るい分け試験を行った. 9月に採取した底質の粒 度分布を砂州の北側汀線と南側汀線とで分けて表示 した結果を図-4と図-5に示寸。北側汀線の底質の粒 度分布である図-4からわかるように中央粒径 $\mathrm{D}_{50}$ は 0.8 1.8mmの範囲にある. 本土側から知林ヶ島に向 かって粒度分布の傾斜が小さくなることが特徽的で ある。また，本土側からと知林ヶ島に向かって底質 粒径全体が相対に大きくなっている。南側汀線の底 質の粒度分布を示した図-5では, 中央粒径 $\mathrm{D}_{50}$ は 1.1 1.9mmの範囲にあることがわかる. 本土側から 知林ヶ島に向かって単純に粒度分布の傾斜が小さく なるのではなく, 砂州中央付近で一旦傾斜が大きく なり，そして再び傾斜が小さくなることがわかる. 一方，北側汀線の底質である図-4の方が南側汀線の 底質である図-5よりも傾きが大きく均等係数が小さ くなることがわかる.

次に, 波浪推算で求めた $\mathrm{H}_{1 / 3}=0.2 \mathrm{~m}, \mathrm{~T}_{1 / 3}=4 \mathrm{~s}$ と高 波浪を想定した $\mathrm{H}=1.0 \mathrm{~m}, \mathrm{~T}=5 \mathrm{~s}$ の波について中央粒 径を $\mathrm{D}_{50}=1.0 \mathrm{~mm}$ として移動限界水深を求めた。 ここ では佐藤・田中の式を参考にパラメータ $n=1 / 3$ $\mathrm{a}=2.4$ (完全移動) と設定した。

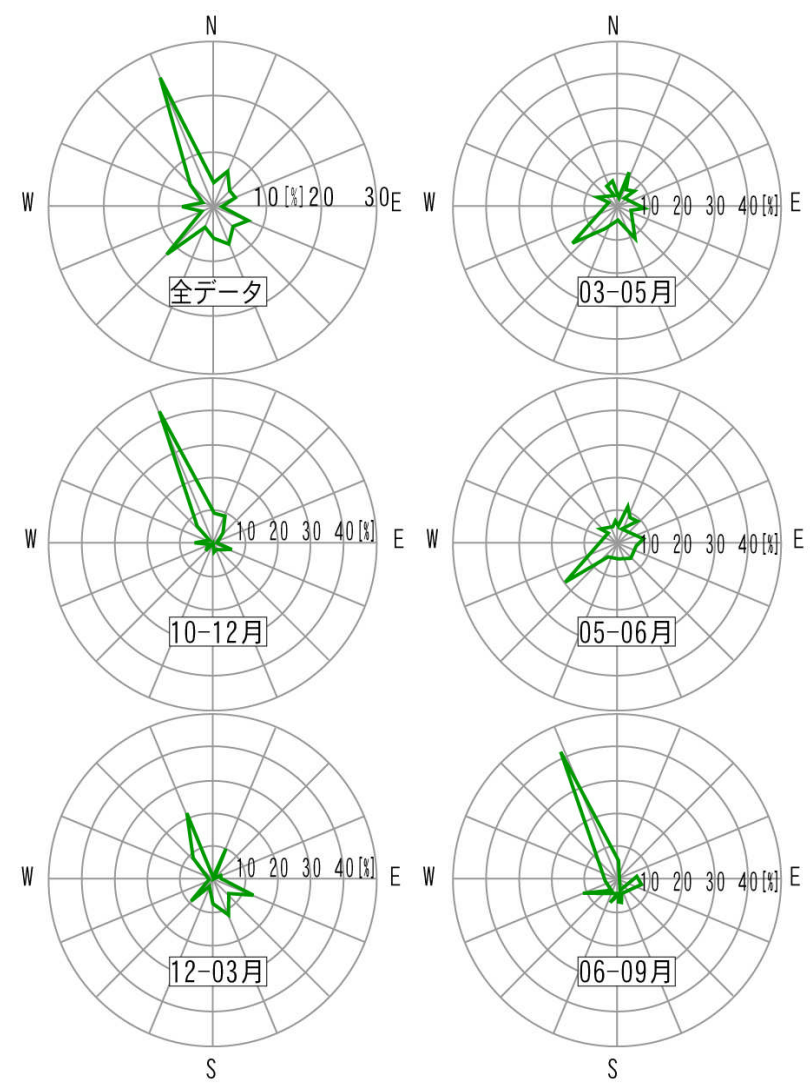

図-2 アメダス気象データの風向頻度分布

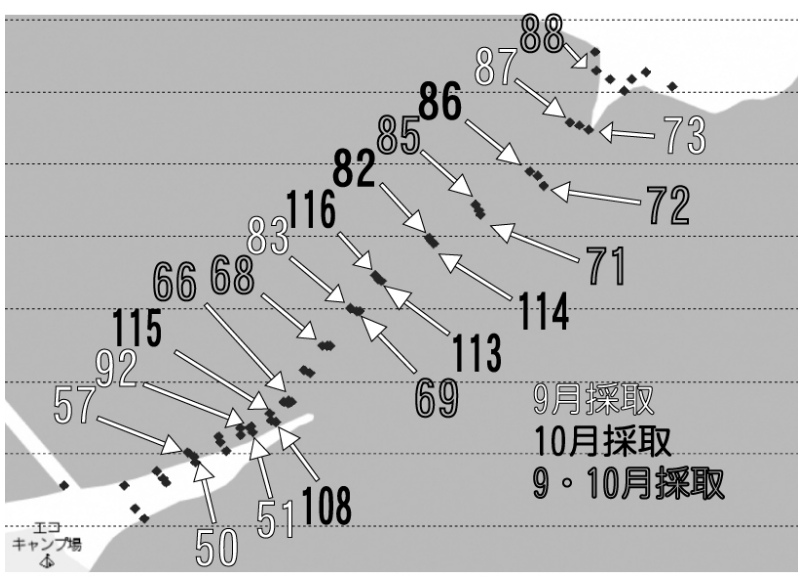

図-3 底質の採取ポイント

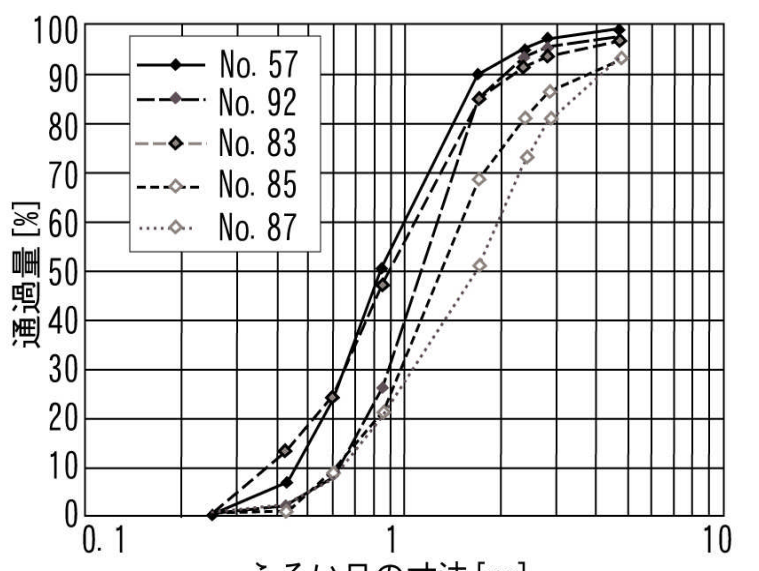

ふるい目の寸法 $[\mathrm{mm}]$

図-4 底質粒度分布 (北側汀線) 


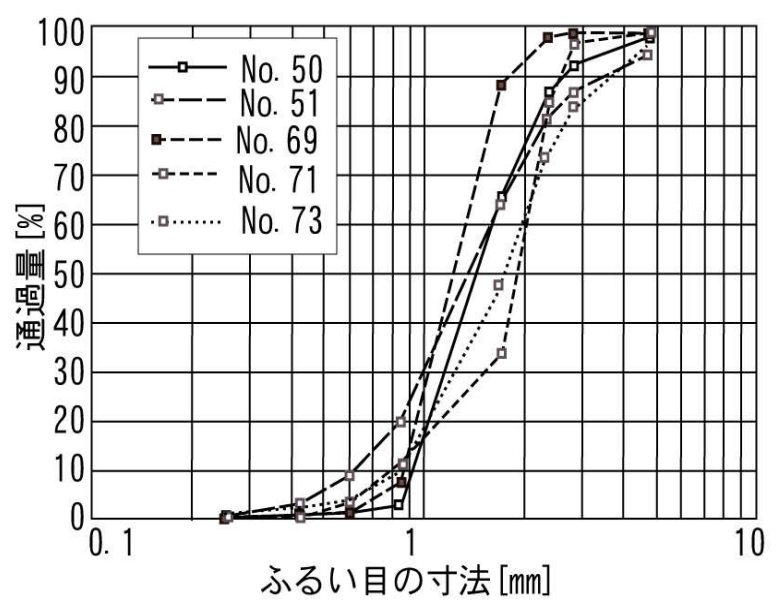

図-5 底質粒度分布 (南側汀線)

その結果，限界水深はそれぞれ $0.4 \mathrm{~m}$ と $1.5 \mathrm{~m}$ と なった。音響測深測量とレベル測量により求められ た砂州周辺の水深図を図-6に示す。この図は平均水 面を基準としている。 また砂州周辺の潮位差は大潮 において $2 \mathrm{~m}$ 程度なので，大潮満潮時に高波浪が作 用すると仮定しても底質は砂州形成位置の指宿海岸 と知林ヶ島の間の狭い領域のみを移動する可能性が 高い。また作用波浪の影響で底質が砂州形成位置に 堆積せずとも，底質は砂州形成位置付近に広く分布 している可能性が高い。つまり砂州を形成している 底質の移動範囲は広くなく, 浅い海域に豊富に存在 する底質が風浪によって寄せられて本砂州の形成機 構が支配されていると考えられる。この機構は, 沿 岸漂砂によって地形先端部から底質が供給され砂州 が伸張していくような砂州形成機構とは大きく異な ることがわかる.

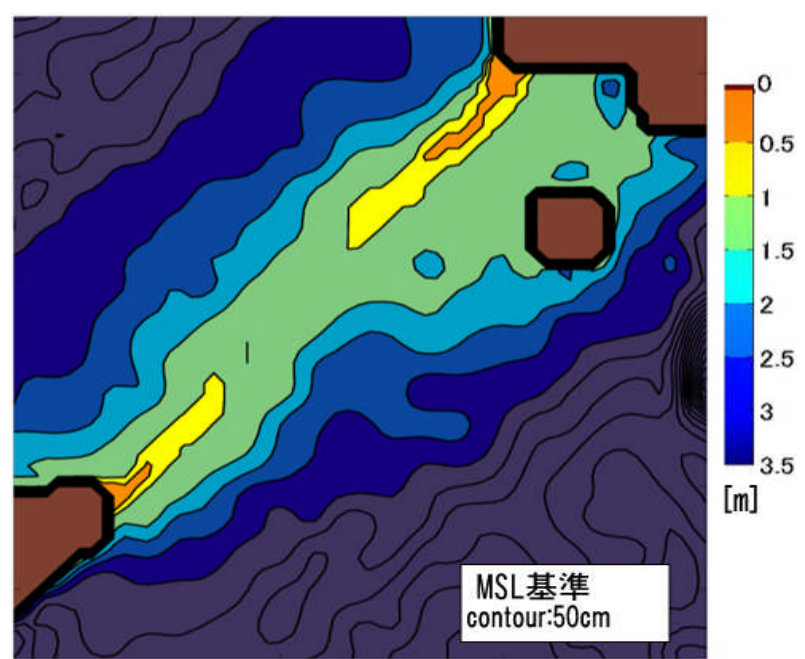

図-6 砂州形成位置の水深図

\section{DPGS による現地観測}

砂州の汀線の経時変化や標高を測定するために DGPS 観測機器を使用した。DGPS受信機には Hemisphere社のA100を使用した。 A100はディファ レンシャル補正情報に対応する測位精度 $0.5 \mathrm{~m}(95 \%)$
を有している。観測ではDGPS観測機器を背負い, 砂州の出現部分の水際(これを砂州観測時の汀線と 定義する)を歩行し, その経度・緯度・高度・時間 を記録した。

今回使用したDGPSによる取得データとレベル測 量による標高データを比較検討することにより DGPS取得データの精度の検討を行った. 砂州上を 約100m間隔で図-7のように7つの断面を決定した。 またレベル測量においては, 砂州中央付近にレベル を設置し汀線付近と汀線と設置機器の中間付近の高 低差を測量した。ここでレベル測量による汀線高は DGPSデータの北側汀線高と一致すると仮定し, 両 者の結果を比較した結果を図-8に示寸. 図から各断 面のDGPSデータとレベル測量データは比較的良く 一致していることがわかる. DGPSデータの標高 データの精度保証は数 $\mathrm{m}$ されているが今回の観測 においては上空付近には障害物が無く, 常時捕捉可 能な衛星の数が多かったためと考えられる。一方, レベル測量とDGPSデータの北側汀線位置の標高 データの一致を仮定しているためか，全断面におい て南側汀線位置の標高データが一致しない。また, 断面01は他の断面と比べてデータの誤差が大きく なった. これは断面01の断面幅が他の断面に比べ2 倍ほど大きいことによると考えられる.

2010年3月1日と7月27日にDGPSによる砂州の断 面形状の測量(図-9)を行った。これまでにこの期間 で砂州全体が南北に移動するサイクルを有すること がわかっている2).つまり3月と7月では砂州の断面 位置は正確には一致しない，本報では，特に砂州の 断面形状について考察するために, 砂州の北汀線位 置を3月と7月で便宜上一致させて考察を行った。こ の図より砂州安定期初期の3月においては, どの断 面においても北側が緩勾配となり, 南側においては 急勾配になっている.しかし, 砂州安定期中盤であ る7月においては，3月の断面形状と比べ北側の勾配 が急になり南側においては勾配が緩やかになる傾向 がわかる.さらに長期の現地観測を行うと砂州出現 期間中はこの傾向が継続し, 最終的には北側が急勾 配になり南側が緩勾配となる結果を得た.

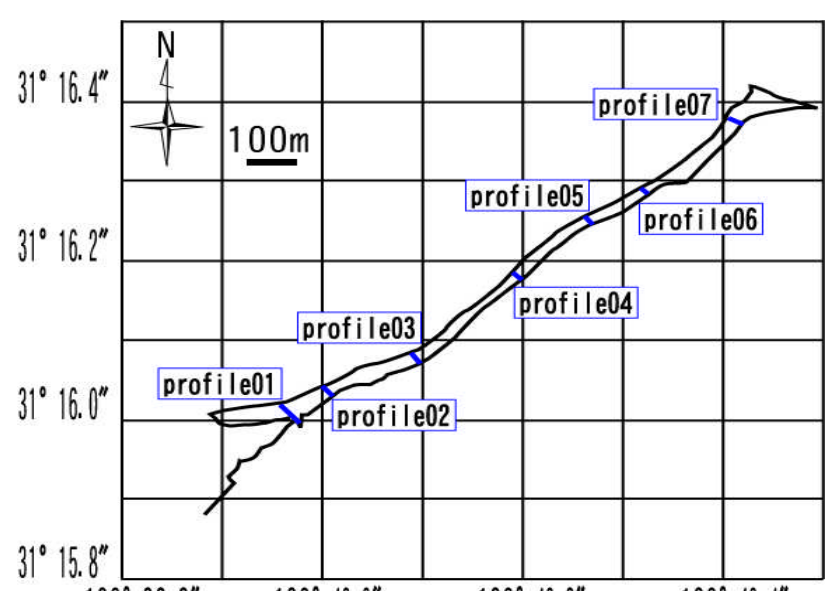

図-7 砂州上の断面 


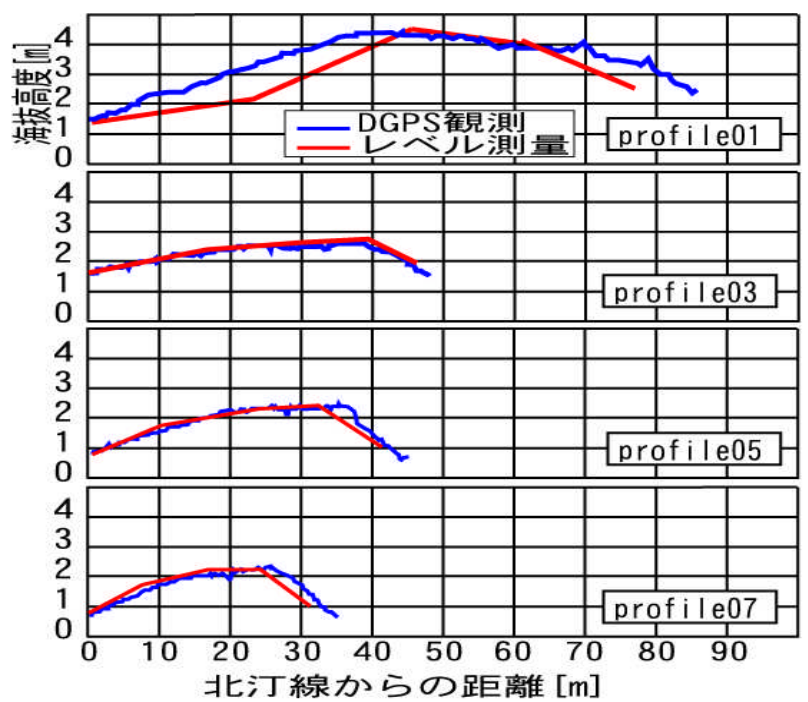

図-8 DGPSデータとレベルデータとの断面形状の比較
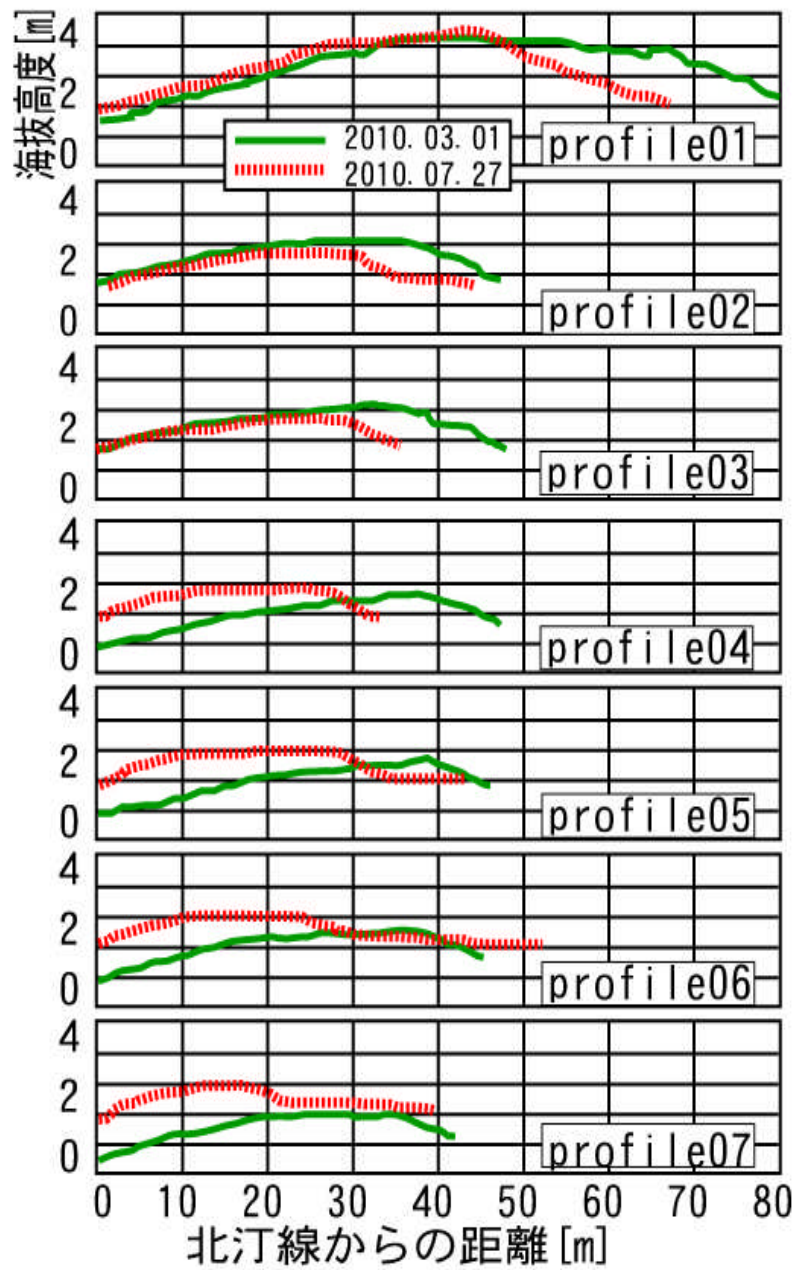

図-9 砂州の断面形状の比較

\section{5. 定点カメラ観測}

定点カメラ観測のための観測塔(図-10)を砂州が 一望できる魚見岳に設置した。砂州と魚見岳は直線 距離で $2 \mathrm{~km}$ であり，魚見岳は標高 $214 \mathrm{~m}$ で知林ヶ島 は最高点の標高が $98 \mathrm{~m}$ ，砂州は海抜 $4 \mathrm{~m}$ 程度となる。

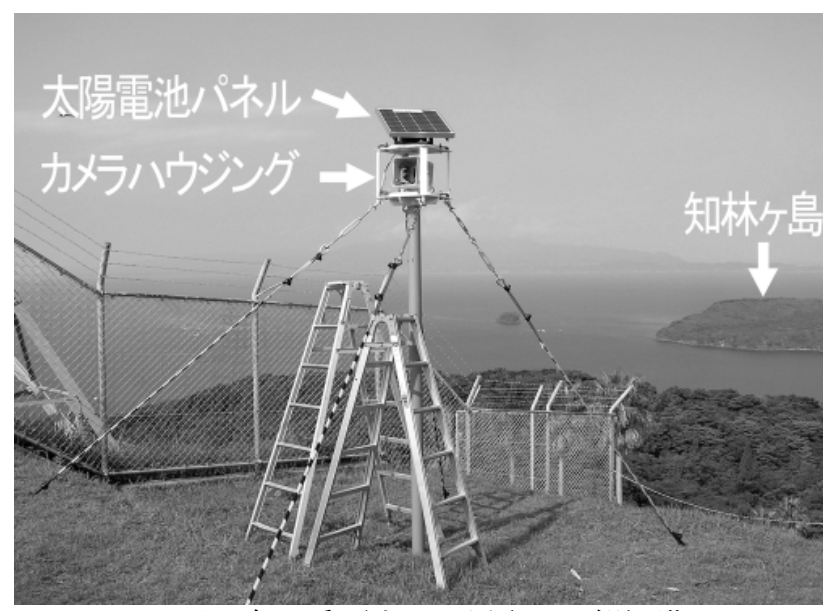

図-10 魚見岳頂上に設置された観測塔

この観測塔に設置しているデジタルカメラから得 られる写真データを使用し砂州地形の変動過程を検 討した。本研究では，単一写真からオルソフォトを 作成する方法として2次元射影変換を採用した。し かし，この射影変換後の画像がどの程度，整合性の 取れたデータになっているか検討する必要があった。 そこで，このオルソフォトと航空写真を比較した (図-11). オルソフォトは2009年4月26日14:00に撮影 されたものを射影変換したものであり，航空写真は 2006年8月9日12:53に撮影されたものである。この 図より，オルソフォトと航空写真の整合性は全体的 に良好だといえる．砂州の汀線位置が合致しないの は撮影日時が異なるためであるが，砂州形成位置は 問題のない範囲に存在している。また砂州の中央右 よりにある岩場の位置は正確に一致している。しか し, 知林ヶ島付近の砂州の位置は一致していない. これは，知林ヶ島が高低差を含むので2次元射影変 換では正確に地形を再現できなかったことによる. 以上より射影変換した画像は，実際の砂州の形状に 関して多少の誤差を含むが今回の検討を行うには十 分な精度を持っていると考える。

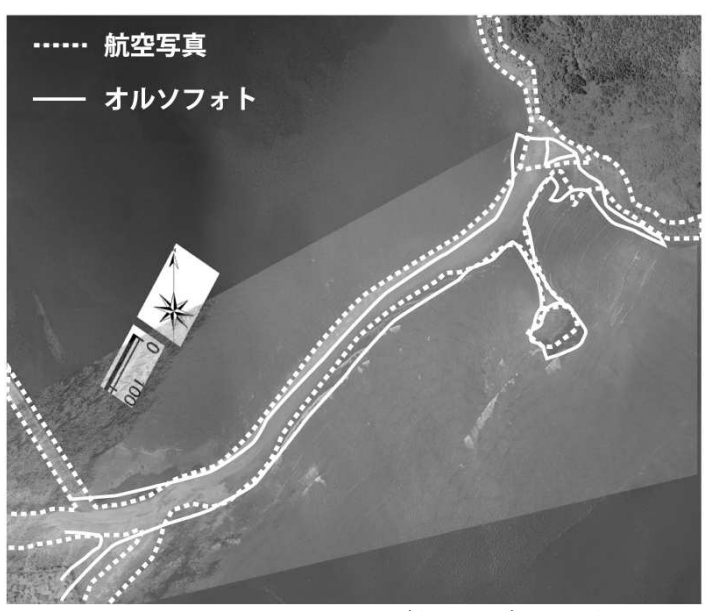

図-11 オルソフォトと航空写真の比較

図-12は，砂州の安定期前半(5月25日)のHWL(図 上)MSL(図中央)LWL(図下)時の射影変換画像であり 岩場の位置を線で囲んでいる。この図から, 砂州は 
安定期においてもHWL時では砂州全体が水没して いることがわかる。また，MSL時においても砂州 中央付近が水没していることがわかる. 以上より, 砂州は安定期であっても潮汐変動に合せて出現・形 成・消滅を繰り返すという日変動を有していること がわかる。

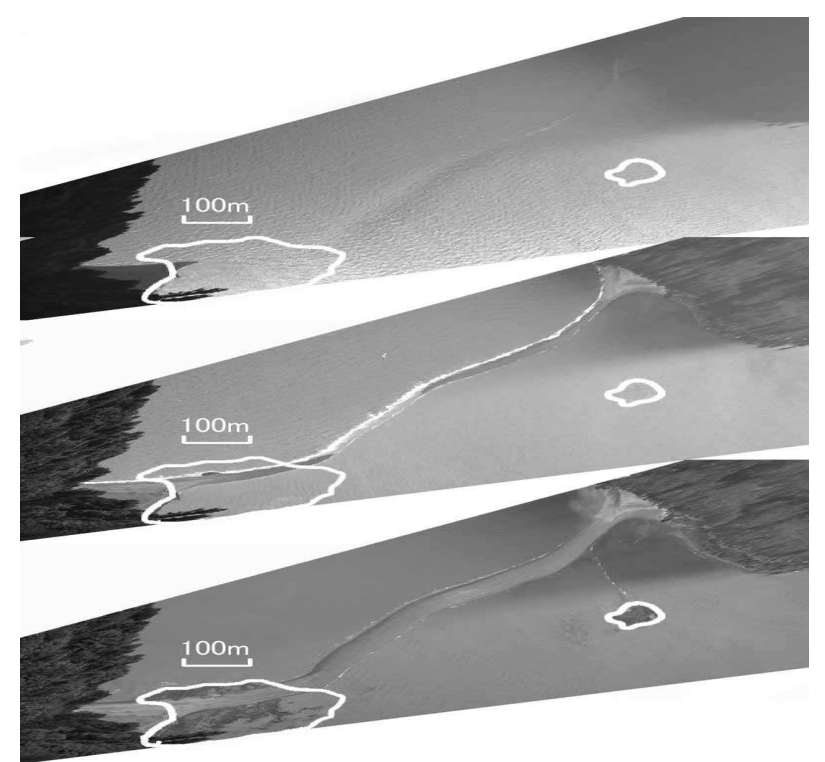

図-12 砂州形成安定期の各潮位での砂州の様子

図-13と図-14に2008年10月から2009年09月までの 約1年間の砂州の移動量と断面幅の変化を示す. 図一 13の砂州の移動量は10月の砂州位置を基準とし北方 向を正值, 南方向を負值で示した. 図-13より遷移 期から安定期前半である3月から6月にかけて砂州全 体が北上を開始し, 安定期後半の10月から消滅期に あたる12月にかけて砂州全体が南下寸ることがわか る。図-14において3月から9月まで各断面における 断面幅は増減が繰り返される結果となった。これら の結果を総合すると, 砂州の出現期初期において, まず砂州の断面幅がある程度まで増加すると砂州全 体が北上を開始する. 砂州の北上と同時に断面幅は 減少する. さらに安定期後半において砂州全体が南 下し始めると断面幅は再度増加することがわかった。

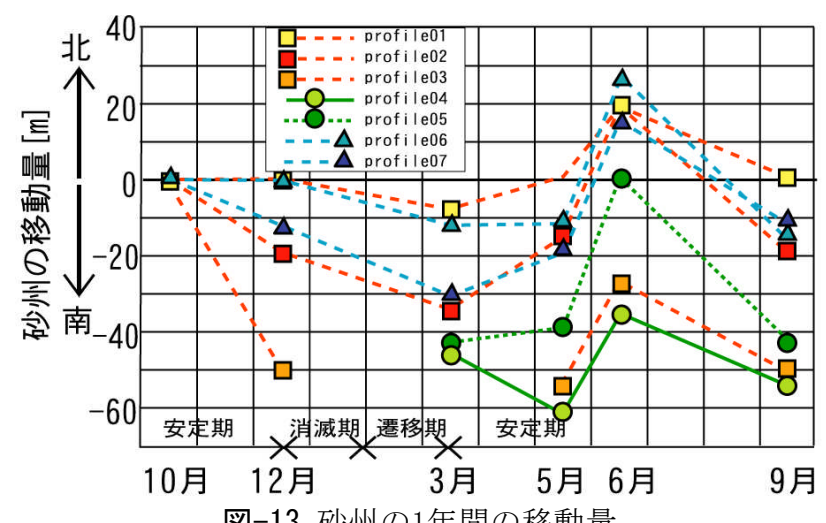

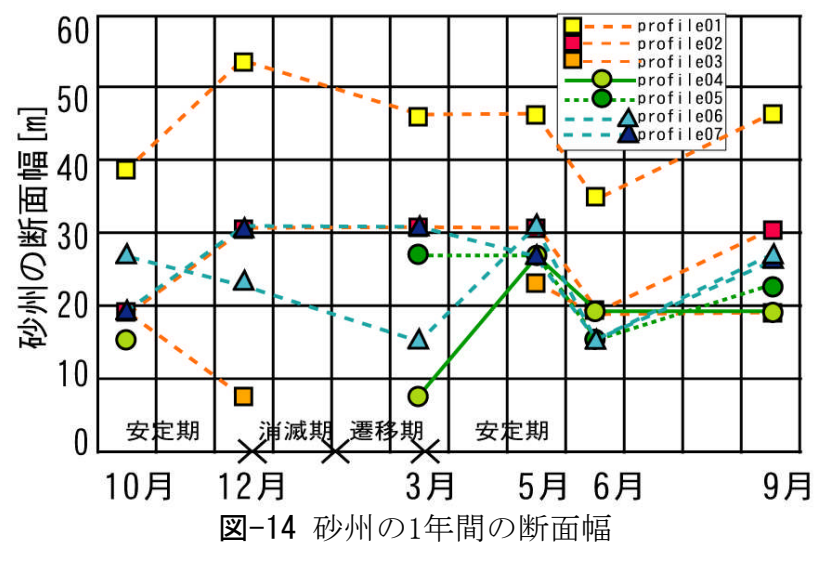

砂州の安定期初期において平均出現潮位時におい ても必ずしも砂州が出現しないことが数回確認でき た(図-15)。この図の左部は3月27日, 右部は4月1日 の平均出現潮位時の砂州の様子を示寸。安定期にお いて砂州は平均出現潮位時において3月27日のよう に形成され，かなり太くなっているのが一般的であ るが，4月1日に限り砂州は形成が遅れている。 そこ で, 砂州の消滅から出現までの1サイクルずつの最 大瞬間風速をまとめたものを図-16に示す. 図の横 軸はデータの累積数でありカウントと表記している. 3月27日のデータは3月 26 日の 16:00から3月 27日の 10:30のデータを示し，4月1日のデータは3月31日の 19:00〜4月1日の14:30のデータを示している.この 結果から最大風速 $6 \mathrm{~m} / \mathrm{s}$ 以下では砂州の出現が遅延し ないことが分かり, 出現の遅延は最大風速 $12.1 \mathrm{~m} / \mathrm{s}$ で起こることがわかった. また, 砂州の出現する直 前(ここではカウントの数が後半部分)に風速が著し く大きくなることがわかった。 それぞれ砂州出現の 6 時間前からの平均風速を求めると，3月27日では $2.1 \mathrm{~m} / \mathrm{s}$ となり一方，4月 1 日では $9.0 \mathrm{~m} / \mathrm{s}$ となり大きな 差が生じた。つまり砂州出現直前の風場が, 砂州出 現に大きく影響することが予想された。またこの風 は, 北から作用していることも分かった. 以上の結 果から，砂州出現直前に北からの強い風が作用寸る と砂州の出現が遅れることがわかった.

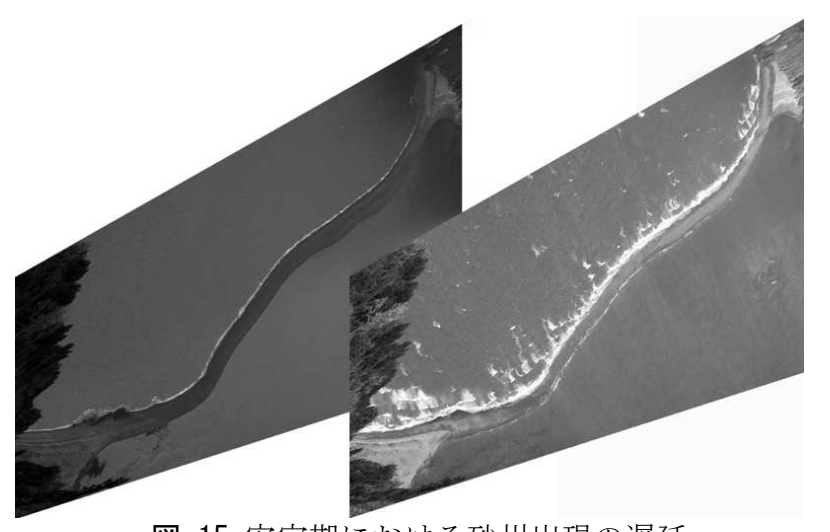

図-15 安定期における砂州出現の遅延 


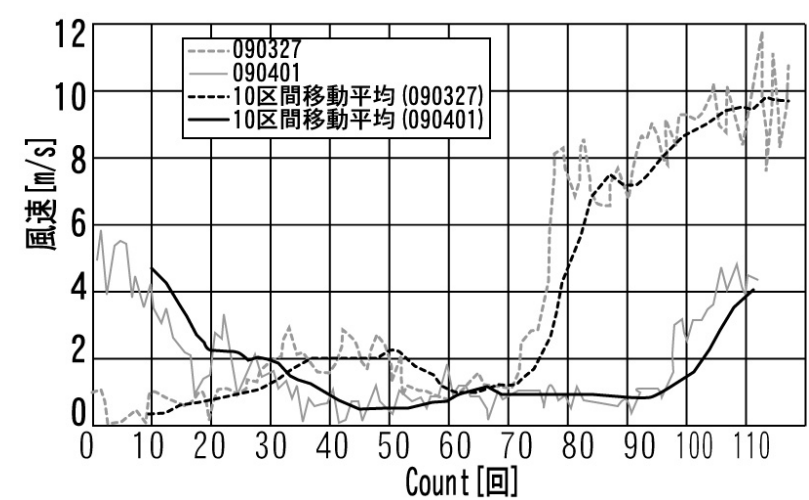

図-16 砂州出現の遅延時と通常時の風速の比較

\section{6. 数値モデルによる検討}

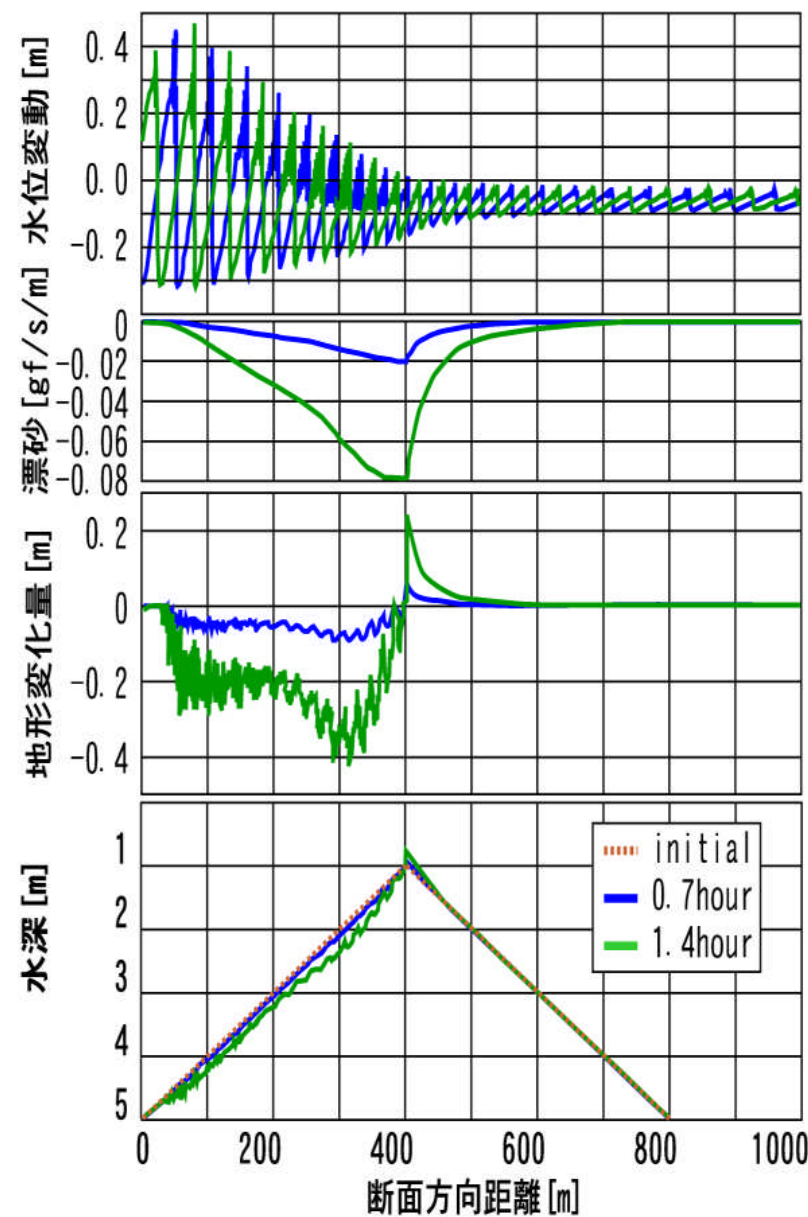

図-17 砂州の断面形状特性に関する数值計算結果

次に，砂州の断面勾配がどのように変化するかを 検討するために1次元浅水方程式，Bailard漂砂量公 式, 漂砂の連続式を使用し, 砂州断面がどのように 地形変化するのかを検討した.

これまでの研究 ${ }^{12)}$ で砂州周辺の波浪場・流れ 場・漂砂場を数值実験によって再現することを検討 している。
作用波浪は砂州が湾内に位置し，その吹送距離を 考えて推算した值である $\mathrm{H}=0.25 \mathrm{~m} ， \mathrm{~T}=4 \mathrm{~s}$ を設定した. 図-17に0.7hour, 1.4hour後の計算結果を示す。この 図により砂州の断面をモデル化した斜面に波が作用 寸ると，波は浅水変形を起こし波高が増大寸る.さ らに水深が浅くなると波高は徐々に小さくなる。漂 砂は，波浪が作用する前面斜面の広い範囲で発生し， 背後斜面では断面の頂点付近のみで発生することが 認められる。地形変化については，前面斜面全域で 侵食が発生し，背後斜面においては断面の頂上付近 で堆積が発生している結果となった。今回の計算に おいては, 計算進行に伴う地形変化を波の変形計算 にフィードバックしていないことや，地形変化計算 に局所的な断面勾配を考慮しておらず，実現象の一 部について正確な再現ができていない。しかし，風 波の作用寸る前面斜面において侵食が発生し，背後 斜面に堆積が起こるといった一連の砂州の断面変化 の特性は表現できているといえる.

\section{7. まとめ}

(1) 底質の振るい分け試験とアメダス気象データ による波浪推算による移動限界水深の算定結果から， 砂州を構成している底質は知林ヶ島と本土側の間の 狭い領域のみを移動することが推測できた。

(2) 定点カメラ観測より砂州は安定期前半(3月〜 6月)に全体的な北上を開始し，安定期後半から消滅 期にかけて(10月〜12月)南下寸ることがわかった。 これは現地の卓越風向の変化と一致している。また, 砂州の北上・南下の時期と砂州の断面幅の増減は関 連することが判明した。

(3) 砂州の断面形状に関する現地観測結果から, 砂州の北上と同時に砂州の断面勾配は北側が緩勾配 から徐々に急勾配に変化し，南側の断面勾配は逆の 挙動を示寸ことがわかった。

(4) 数值計算により, 現地の砂州の断面勾配の変 化は，作用寸る風波によって支配されることが確認 された。この特性は定点カメラ観測で得られた砂州 全体の北上・南下の移動過程とも深く関わっている ことが推測できる.

\section{参考文献}

1）長山昭夫，山口裕之，茶屋彰仁，田中龍児，中村和夫, 浅野敏之: 指宿知林ヶ島陸繋砂州の形成・消滅過程に 関する基礎的研究, 土木学会論文集 B2 (海岸工 学), VolB2-65, No. 1, pp. 586-590, 2009

2) 長山昭夫, 谷山昌弘, 川上弘次, 浅野敏之: 指宿知 林ヶ島陸繋砂州の年間を通じた変動過程に関する研究, 土木学会論文集B2(海岸工学), Vol66, No. 1, pp. 156160,2010 